\title{
CHANGES IN STATE INCOME INEQUALITY FROM 1981 TO 1987
}

\author{
Thomas A. Husted ${ }^{*}$
}

\begin{abstract}
This paper examines the changes in state-level income inequality from 1981 to 1987. Family income inequality is measured with Gini coefficients calculated for each state. Changes in these measures during this period appear to reflect, in part, the uneven economic restructuring across the states and regions during the 1980s.
\end{abstract}

\section{INTRODUCTION}

There has been substantial economic growth in many of the individual states, as well as in the United States, following the recession of the early 1980s. Total gross state product (GSP) grew from $\$ 3,104,127$ million in 1982 to $\$ 4,191,705$ million in 1986, and the average state unemployment rate declined from 9.23 percent to 6.95 percent. $^{1}$ One surprising characteristic of this post-recession economic expansion, however, is the significant increase in the income gap between rich and poor families in the United States. ${ }^{2}$ Between 1979 and 1988, mean cash family income (1988 dollars) declined by 5.1 percent in the lowest quintile and by 2.0 percent in the second lowest quintile, while the highest quintile increased by 11.8 percent. $^{3}$

This paper focuses on state-level family income inequality from 1981 to 1987 in order to determine whether state-level family income inequality patterns reflect the general U.S. experience of increasing inequality. Inequality is measured by the state's Gini coefficient, as calculated from each state's Lorenz curve. ${ }^{4}$ These state-level Gini coefficients indicate that while family income inequality has grown in the states, this growth has not been uniform. One possible explanation for these differences across states is then considered.

\section{ESTIMATION OF THE LORENZ CURVE AND GINI COEFFICIENT CALCULATIONS}

The Gini coefficient is a well-known summary measure of inequality. It is derived from the Lorenz curve, which describes the proportion of total income or

\footnotetext{
*Assistant Professor of Economics, The American University. The author would like to thank the editors, Robert Feinberg, D.J. Slottje, and two anonymous referees for helpful comments and suggestions.
} 
wealth received by each percentage of the specified population unit (e.g., family, household, individual). ${ }^{5}$ The Gini coefficient ranges from 0 when all units have equal incomes to 1 when a single unit has 100 percent of total income or wealth in the economy. This paper uses techniques developed in Kakwani and Podder $(1973,1976)$ and described in Slottje (1989) to estimate state-level Lorenz curves. The parameter estimates are then used to calculate the associated Gini coefficients and their asymptotic standard errors.

Following Kakwani and Podder (1976), family income $\mathrm{Y}$ is a random variable with probability density function $\mathrm{f}(\mathrm{Y})$, so that

$$
P(Y)=\int_{0}^{y} f(Y) d Y
$$

is the proportion of families with income less than or equal to $y$ and

$$
Q(Y)=(1 / \mu) \int_{o}^{y} Y \mathrm{f}(Y) d Y
$$

is the proportion of income earned by the families who have incomes less than or equal to $y$, where $\mu$ represents the mean income of all families in the population.

Given these definitions, any point on a Lorenz curve can be described by two line segments,

$$
\pi=(1 / \sqrt{ } 2)[P(Y)+Q(Y)] \text { and } \sigma=(1 / \sqrt{ } 2)[P(Y)-Q(Y)] .
$$

The first line segment $(\pi)$ is the ordinate from the point on the Lorenz curve to the diagonal egalitarian line. The second segment $(\sigma)$ extends from the origin to this ordinate along the diagonal egalitarian line. It follows from these definitions that

$$
d \pi / d \sigma=(\mu-y) /(\mu+y) \text {. }
$$

The proposed Lorenz curve for this study is

$$
\sigma=a \pi^{\alpha}(\sqrt{2}-\pi)^{\beta} \text {, where } 0<\pi<\sqrt{2} \text {, and } a, \alpha \text {, and } \beta \text { are }>0 .{ }^{6}
$$

Taking the log of both sides, Equation (5) becomes

$$
\log (\sigma)=\log (a)+\alpha \log (\pi)+\beta \log (\sqrt{ } 2-\pi)
$$


This specification satisfies the necessary properties for a Lorenz curve. ${ }^{7}$ In particular, $\sigma \geq 0$ when a $>0$ and the Lorenz curve lies below the egalitarian line. The parameters $\alpha$ and $\beta$ are restricted to be greater than zero, so that $\sigma=0$ when $\pi=0$ or $\pi=\sqrt{2}$. Additional restrictions are imposed by Equation (4) and the negative second derivative. These additional restrictions constrain $0<\alpha \leq 1$ and $0<\beta \leq 1$ and indicate for the Lorenz curve defined in Equation (5) that ${ }^{8}$

$$
\alpha(\sqrt{ } 2-\pi)-\beta \pi=[(\mu-y) /(\mu+y)] \pi(\sqrt{ } 2-\pi) / \sigma .
$$

In order to calculate the Gini coefficient, the parameters of the Lorenz curve in Equation (5') and the restrictions on this curve in Equation (6) must be jointly estimated. However, since the available income data for this analysis are grouped by income class, $\pi$ and $\sigma$ are not observed. In these data, there are $N$ families grouped into $\mathrm{K}+1$ income classes for each time series $t(t=1, \ldots, T)$ and within each cross section $c(c=1, \ldots, C)$. If $n_{t, c}$ is the number of families earning incomes between $\mathrm{y}_{\mathrm{k}-1}$ and $\mathrm{y}_{\mathrm{k}}$ in time period $\mathrm{t}$ and cross section $\mathrm{c}$, then $\mathrm{f}_{\mathrm{t}, \mathrm{c}}^{\mathrm{k}}=$ $\mathrm{n}_{\mathrm{t}, \mathrm{c}}^{\mathrm{k}} / \mathrm{N}$ is a consistent estimator of the probability that a family belongs to this particular income group in cross section $\mathrm{c}$ and year $\mathrm{t}$. Therefore, the estimators of $\mathrm{P}(\mathrm{Y})$ and $\mathrm{Q}(\mathrm{Y})$ are

$$
\begin{aligned}
p_{t, c}^{k} & =\sum_{f_{\delta=1 \delta}}^{k} \text { for each } \mathrm{t}=1, \ldots T \text { and } c=1, \ldots, C \text { and } \\
q_{t, c}^{k} & =\left(1 / \mu_{t, c}\right) \sum_{\delta \sim=1}^{k} m_{\delta} \mathrm{f}_{\delta} \text { for each } t=1, \ldots, T \text { and } c=1, \ldots, C,
\end{aligned}
$$

where $\mathrm{m}_{\delta}$ is the mean income for income group $\delta$, and $\mu_{\mathrm{t}, \mathrm{c}}$ is the mean income for all families in crosssection $c$ and in year $t$. By substituting $\mathrm{p}_{\mathrm{t}, \mathrm{c}}^{\mathrm{k}}$ and $\mathrm{q}_{\mathrm{t}, \mathrm{c}}^{\mathrm{k}}$ into the expressions in Equation (3), consistent estimators of $\pi$ and $\sigma$ are

$$
l_{t, c}^{k}=\left[p_{t, c}^{k}+q_{t, c}^{k}\right] / \sqrt{ } 2 \text { and } n_{t, c}^{k}=\left[p_{t, c}^{k}-q_{t, c}^{k}\right] / \sqrt{ } 2 \text {. }
$$

Since these estimators differ from the true $\pi$ and $\sigma$ by a random disturbance, then Equation (5') is expressed as

$$
\log \left(n_{t, c}^{k}\right)=a^{\prime}+\alpha \log \left(1_{t, c}^{k}\right)+\beta \log \left(\sqrt{2}-1_{t, c}^{k}\right)+e_{1} .
$$

Finally, after substituting $\mathrm{p}_{t, \mathrm{c}}^{\mathrm{k}}$ and $\mathrm{q}_{\mathrm{t}, \mathrm{c}}^{\mathrm{k}}$ for $\pi$ and $\sigma$, Equation (6) becomes 


$$
\left.\left[\left(\mu_{t, c}-y_{k}\right) /\left(\mu_{t, c}-y_{k}\right)\right]\left[\sqrt{ } 2-1_{t, c}^{k}\right) / n_{t, c}^{k}\right]=\alpha\left(\sqrt{ }-1_{t, c}^{k}\right)-\beta\left(1_{t, c}^{k}\right)+e_{2} .
$$

A joint generalized least squares (GLS) estimation of the proposed Lorenz curve in Equation (7) and its restrictions in Equation (8) is carried out on statelevel grouped pre-tax family income data. ${ }^{9}$ This estimation is more efficient than the ordinary least squares estimation of the Lorenz curve parameters in Equation (7). ${ }^{10}$ With the estimated coefficients from the GLS estimation $-\mathrm{a}, \alpha$, and $\beta$ - Gini coefficients can be calculated. The Gini coefficient for each state derived from the Lorenz curve in Equation (7) is

$$
G=2 a(\sqrt{ } 2)^{1+\alpha+\beta} \beta_{B(1+\alpha, 1+\beta),}
$$

where $B(1+\alpha, 1+\beta)$ is the Beta function, with $1+\alpha$ and $1+\beta$ degrees of freedom.

\section{DATA}

The grouped income data used for this study are unpublished state-level data from 1981-1987 obtained from the U.S. Department of Commerce, Bureau of the Census. They are taken from the March Current Population Survey and represent money income received before personal income tax and social insurance payments. These annual data contain the numbers of families in 21 income class intervals-from under $\$ 2,500$ to $\$ 75,000$ and over-for each state as well as the state's overall mean and median income levels. ${ }^{11}$ As specified above, the mean income levels for each income class interval are required to determine $1_{t, c}^{k}$ and

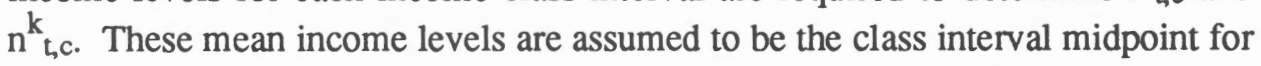
the first 20 income class intervals up to and including $\$ 74,999$, and $\$ 82,000$ for the $\$ 75,000$ and over class.

\section{STATE GINI COEFFICIENTS, 1981-1987}

The calculated Gini coefficients and their standard errors for 1981 and 1987 are presented in the Table $1 .{ }^{12}$ The increasing average of Gini coefficients reflects the growth in family income inequality observed in the United States between 1981 and 1987. Thirty states have their largest Gini coefficient (indicating the greatest level of family income inequality) in either 1986 or 1987 . The last column in Table 1 shows the percent change in the Gini coefficient for each state 
TABLE 1

Gini Coefficients by Region and State, 1981 and 1987

(Standard Errors in parentheses)

\begin{tabular}{lccc}
\hline & & Percent Change \\
State & 1981 & 1987 & $1981-1987$ \\
\hline
\end{tabular}

New England

Connecticut

0.313612

0.364747

16.30

Maine

$(0.0236)$

(0.0239)

0.354497

(0.0180)

$(0.0167)$

Massachusetts

0.336279

0.368226

(0.0260)

(0.0237)

New Hampshire

0.345699

0.324030

(0.0186)

Rhode Island

0.332879

$(0.0332)$

0.355502

(0.0255)

Vermont

0.319749

(0.0242)

(0.0266)

0.362343

(0.0166)

4.18

9.50

$-6.27$

6.80

13.32

AVERAGE

Middle Atlantic

New Jersey

0.353796

(0.0242)

0.356208

0.68

New York

0.370234

$(0.0275)$

0.407711

(0.0232)

(0.0213)

Pennsylvania

0.339720

0.363572

(0.0226)

(0.0232)

10.12

7.02

5.94

\section{East-North-Central}

$\begin{array}{lrrr}\text { Illinois } & 0.357007 & 0.391200 & 9.58 \\ & (0.0265) & (0.0313) & \\ \text { Indiana } & 0.334404 & 0.370562 & 10.81 \\ & (0.0096) & (0.0178) & 10.59 \\ \text { Michigan } & 0.342343 & 0.378608 & \\ & (0.0261) & (0.0226) & 7.68 \\ \text { Ohio } & 0.344893 & 0.371389 & 10.08 \\ & (0.0203) & (0.0280 & \\ \text { Wisconsin } & 0.323749 & 0.356383 & 9.75 \\ \text { AVERAGE } & (0.0274) & (0.0273) & \\ & & & \\ \text { est-North-Central } & & & -7.07 \\ \text { Iowa } & & & \\ \text { Kansas } & (0.0166) & (0.0269) & -0.70 \\ & 0.334952 & 0.332591 & (0.0195) \\ & (0.0143) & & \end{array}$


TABLE 1 (Continued)

\begin{tabular}{|c|c|c|c|}
\hline Minnesota & $\begin{array}{r}0.330114 \\
(0.0233)\end{array}$ & $\begin{array}{r}0.361162 \\
(0.0210)\end{array}$ & 9.41 \\
\hline Missouri & $\begin{array}{r}0.375845 \\
(0.0194)\end{array}$ & $\begin{array}{r}0.374326 \\
(0.0250)\end{array}$ & -0.40 \\
\hline Nebraska & $\begin{array}{r}0.365658 \\
(0.0199)\end{array}$ & $\begin{array}{r}0.346199 \\
(0.0162)\end{array}$ & -5.32 \\
\hline North Dakota & $\begin{array}{c}0.398562 \\
(0.0186)\end{array}$ & $\begin{array}{r}0.343105 \\
(0.0216)\end{array}$ & -13.91 \\
\hline South Dakota & $\begin{array}{r}0.369814 \\
(0.0194)\end{array}$ & $\begin{array}{r}0.353593 \\
(0.0182)\end{array}$ & -4.39 \\
\hline AVERAGE & & & -3.20 \\
\hline \multicolumn{4}{|l|}{ South Atlantic } \\
\hline Delaware & $\begin{array}{r}0.355385 \\
(0.0156)\end{array}$ & $\begin{array}{r}0.346003 \\
(0.0283)\end{array}$ & -2.64 \\
\hline Florida & $\begin{array}{r}0.380927 \\
(0.0100)\end{array}$ & $\begin{array}{r}0.400696 \\
(0.0143)\end{array}$ & 5.19 \\
\hline Georgia & $\begin{array}{r}0.376732 \\
(0.0188)\end{array}$ & $\begin{array}{r}0.386445 \\
(0.0240)\end{array}$ & 2.58 \\
\hline Maryland & $\begin{array}{r}0.363335 \\
(0.0189)\end{array}$ & $\begin{array}{r}0.349790 \\
(0.0255)\end{array}$ & -3.73 \\
\hline North Carolina & $\begin{array}{r}0.359555 \\
(0.0188)\end{array}$ & $\begin{array}{r}0.388450 \\
(0.0208)\end{array}$ & 8.04 \\
\hline South Carolina & $\begin{array}{r}0.359202 \\
(0.0208)\end{array}$ & $\begin{array}{r}0.366904 \\
(0.0208)\end{array}$ & 2.14 \\
\hline Virginia & $\begin{array}{r}0.369039 \\
(0.0218)\end{array}$ & $\begin{array}{r}0.383987 \\
(0.0203)\end{array}$ & 4.05 \\
\hline West Virginia & $\begin{array}{r}0.334577 \\
(0.0413)\end{array}$ & $\begin{array}{r}0.410743 \\
(0.0223)\end{array}$ & 22.76 \\
\hline AVERAGE & & & 4.80 \\
\hline \multicolumn{4}{|l|}{ East-South-Central } \\
\hline Alabama & $\begin{array}{r}0.388854 \\
(0.0126)\end{array}$ & $\begin{array}{r}0.403177 \\
(0.0176)\end{array}$ & 3.68 \\
\hline Kentucky & $\begin{array}{r}0.382584 \\
(0.0148)\end{array}$ & $\begin{array}{r}0.382218 \\
(0.0170)\end{array}$ & -0.10 \\
\hline Mississippi & $\begin{array}{r}0.415589 \\
(0.0215)\end{array}$ & $\begin{array}{r}0.429114 \\
(0.0205)\end{array}$ & 3.25 \\
\hline Tennessee & $\begin{array}{r}0.367928 \\
(0.0168)\end{array}$ & $\begin{array}{r}0.386094 \\
(0.0231)\end{array}$ & 4.94 \\
\hline AVERAGE & & & 2.94 \\
\hline \multicolumn{4}{|l|}{ West-South-Central } \\
\hline Arkansas & $\begin{array}{r}0.380595 \\
(0.0160)\end{array}$ & $\begin{array}{r}0.416372 \\
(0.0139)\end{array}$ & 9.40 \\
\hline Louisiana & $\begin{array}{r}0.411566 \\
(0.0260)\end{array}$ & $\begin{array}{r}0.411311 \\
(0.0277)\end{array}$ & -0.06 \\
\hline Oklahoma & $\begin{array}{r}0.367327 \\
(0.0136)\end{array}$ & $\begin{array}{c}0.385858 \\
(0.0186)\end{array}$ & 5.04 \\
\hline
\end{tabular}




\begin{tabular}{|c|c|c|c|}
\hline Texas & $\begin{array}{r}0.405429 \\
(0.0178)\end{array}$ & $\begin{array}{r}0.403461 \\
(0.0210)\end{array}$ & -0.49 \\
\hline AVERAGE & & & 3.47 \\
\hline \multicolumn{4}{|l|}{ Mountain } \\
\hline Arizona & $\begin{array}{r}0.354277 \\
(0.0136)\end{array}$ & $\begin{array}{r}0.406365 \\
(0.0244)\end{array}$ & 14.70 \\
\hline Colorado & $\begin{array}{r}0.351771 \\
(0.0191)\end{array}$ & $\begin{array}{r}0.397937 \\
(0.0213)\end{array}$ & 13.12 \\
\hline Idaho & $\begin{array}{r}0.348990 \\
(0.0196)\end{array}$ & $\begin{array}{r}0.379624 \\
(0.0090)\end{array}$ & 8.78 \\
\hline Montana & $\begin{array}{r}0.332962 \\
(0.0221)\end{array}$ & $\begin{array}{r}0.385386 \\
(0.0211)\end{array}$ & 15.74 \\
\hline Nevada & $\begin{array}{r}0.340985 \\
(0.0187)\end{array}$ & $\begin{array}{r}0.355196 \\
(0.0164)\end{array}$ & 4.17 \\
\hline New Mexico & $\begin{array}{r}0.387189 \\
(0.0150)\end{array}$ & $\begin{array}{r}0.407732 \\
(0.0102)\end{array}$ & 5.31 \\
\hline Utah & $\begin{array}{r}0.349150 \\
(0.0196)\end{array}$ & $\begin{array}{r}0.353031 \\
(0.0132)\end{array}$ & 1.11 \\
\hline Wyoming & $\begin{array}{r}0.321879 \\
(0.0249)\end{array}$ & $\begin{array}{r}0.367029 \\
(0.0239)\end{array}$ & 14.03 \\
\hline AVERAGE & & & 9.62 \\
\hline
\end{tabular}

Pacific

$\begin{array}{lrrr}\text { Alaska } & 0.359921 & 0.369488 & 2.66 \\ \text { California } & (0.0181) & (0.0181) & 4.96 \\ & 0.373524 & 0.392081 & \\ \text { Hawaii } & (0.0160) & (0.0146) & 1.78 \\ & 0.346632 & 0.352795 & 3.51 \\ \text { Oregon } & (0.0278) & (0.0165) & 10.63 \\ \text { Washington } & 0.337809 & 0.349684 & 4.71 \\ \text { AVERAGE } & (0.0255) & (0.0198) & \\ & 0.344957 & 0.381641 & 4.81\end{array}$

column in Table 1 shows the percent change in the Gini coefficient for each state and region between 1981 and 1987. As these percentages indicate, Connecticut, Vermont, Montana, West Virginia, Arizona, Colorado, and Wyoming are among those states with the largest increases in family income inequality. The largest average percentage increases in family income inequality between 1981 and 1987 are in the East-North-Central (9.75 percent) and the Mountain (9.62) regions. The East-South-Central (2.94) and West-South-Central regions (3.47) have the lowest 
increases. While New Hampshire, Jowa, Nebraska, North Dakota, South Dakota, Delaware, and Maryland each have a greater than 1 percent decline in their Gini coefficients between 1981 and 1987, the West-North-Central is the only region with an average decrease $(-3.20)$ in family income inequality.

Although there are significant differences among the states and regions in the growth of income inequality, there is a considerable amount of continuity in the overall rankings of the states relative to their 1981 rankings. The states with the lowest levels of inequality are Connecticut in 1981 (0.313) and New Hampshire in 1987 (0.324). Furthermore, New Hampshire has the smallest Gini coefficients in each year between 1982 and 1987. The state with the greatest level of inequality in both 1981 (0.415) and 1987 (0.429) is Mississippi. Between 1981 and 1987, Mississippi ranked at or near the bottom of the 50 states. Twenty-five states changed their relative ranking by fewer than 10 positions between 1981 and 1987.

\section{ONE EXPLANATION FOR DIFFERENCES IN INCOME INEQUALITY CHANGES}

Although identifying the exact cause of these differences in the changes in state-level family income inequality is beyond the scope of this paper, one possible explanation is briefly explored. Many researchers blame recent increases in earnings inequality on the economic restructuring from relative high-wage to lowwage employment sectors. ${ }^{13}$ In fact, a principal characteristic of the most recent economic expansion is the significant degree of economic restructuring from the high-wage manufacturing, construction, and mining sectors to the low-wage service and trade sectors. Between 1979 and 1987, one-half of the jobs created in the United States were low-wage jobs (below $\$ 11,611$ per year in 1987 and below $\$ 7,564$ in 1979). While the share of low-wage jobs in the economy increased by 3.2 percent, the share of middle-wage jobs (between $\$ 11,612$ and $\$ 46,444$ in 1987 and between $\$ 7,565$ and $\$ 30,254$ in 1979) decreased by 4.0 percent, and the share of high-wage jobs increased by 0.8 percent. ${ }^{14}$

Even though earnings inequality and family income inequality do not necessarily move together, these transformations can affect both earnings and family income levels as changes in labor demand force workers into unemployment or into the expanding lower-wage sectors of the economy. ${ }^{15}$ Blackburn and Bloom (1987) note that the largest changes in family income inequality between 1960 and 1986 can be attributed to supply-side, rather than demand-side, effects, such as changes in family composition and its economic activities resulting in part from this economic restructuring. 
One interesting characteristic of this economic restructuring has been its uneven incidence across the states and regions. For example, all but the New England states experiehced a decline in middle-wage jobs, and only the New England, Mid-Atlantic, and South Atlantic regions had declining shares of lowwage jobs during the 1980s. The largest shift from middle- to low-wage jobs occurred in the East-South-Central and East-North-Central regions, where each experienced at least a 5 percent increase in low-wage jobs.

This uneven economic restructuring may explain the observed differences across the states in family income inequality growth between 1981 and 1987. Four of the states with decreasing inequality are from the West-North-Central region (Iowa, Nebraska, North Dakota, and South Dakota). This region also has the lowest increase ( 2.2 percent) in low-wage jobs (of the regions that recorded an increase in low-wage jobs between 1979 and 1987) and one of the smallest decreases overall (2.4 percent) in middle-wage jobs and one of the smallest increases ( 0.2 percent) in high-wage jobs between 1979 and 1987 . On the other hand, the large increase in inequality in the East-North-Central region reflects the aforementioned large shift of workers from middle-wage to low-wage employment in these states. This region also recorded the largest decrease ( -5.5 percent) in middle-wage jobs between 1979 and 1987. Of the remaining states that experienced a significant increase in inequality, Colorado, West Virginia, and Wyoming suffered serious losses in their mining sectors during this period.

A more formal statistical analysis would have to be carried out to determine whether there is any link between the uneven economic restructuring across the states and regions and the observed regional differences in the growth of income inequality.

\section{CONCLUSIONS}

The calculated state-level Gini coefficients for family income from 1981 to 1987 reflect the increasing inequality observed in the United States during the 1980s. These measures also indicate significant differences in the growth of family income inequality across the states. Although the exact cause of these differences is not explored in this paper, they mirror, in part, the uneven incidence of state-level economic restructuring from high- and middle-wage manufacturing, construction, and mining sectors to the low-wage service and trade sectors. 


\section{ENDNOTES}

1. Renshaw, Trott, and Friedenberg (1988) report GSP figures and state industry sector trends. State unemployment statistics are obtained from the U.S. Department of Commerce.

2. See Bradbury (1986) for evidence of this declining middle class.

3. Using Lorenz curves, Blackburn and Bloom (1991) found an unambiguous erosion of family income inequality between 1979 and 1987 in the United States.

4. These calculations are necessary, since the U.S. Bureau of the Census reports state-level Gini coefficients only for census years.

5. The focus of this paper is on family income distribution. Braun (1988) discusses some of the weaknesses of the Gini coefficient and describes alternative measures of income inequality.

6. Kakwani and Podder (1976) use this Lorenz curve to fit Australian income data.

7. These properties are summarized by Kakwani and Podder (1976).

8. See Kakwani and Podder (1976) for proof.

9. This proposed Lorenz curve provides an excellent fit of the grouped state income data described below. The joint GLS coefficient estimates are available from the author.

10. Kakwani and Podder (1976) formally describe the procedure to estimate these parameters with GLS and then demonstrate the relative efficiency of these parameters.

11. After 1987, grouped income data by state are unavailable.

12. Gini coefficients for 1983-1986 are available upon request from the author. In order to calculate the asymptotic standard errors for each of these Gini coefficients, it is necessary to take the partial derivatives of each Gini coefficient with respect to the three parameters from the Lorenz curve. These partial derivatives require the evaluation of the partial derivatives of the Beta function $B(1+\alpha, 1+\beta)$ with respect to $\alpha$ and $\beta$. These derivatives involve relationships between Euler's psi functions evaluated at different degrees of freedom. This relationship can be numerically calculated using the expression (3.6) in Kakwani and Podder (1976). The calculated derivatives are then combined with the estimated variances and covariances of the parameter estimates to produce the standard errors of the Gini coefficients. Kakwani and Podder $(1973,1976)$ describe this procedure.

13. Leonard and Jacobson (1990), Bluestone (1990), Bluestone and Harrison (1988), Bound and Johnson (1989), and Grubb and Wilson (1989) discuss this economic restructuring. 
14. These data are from U.S. Congress $(1990,526-27)$. It appears that much of this increase in the low-wage jobs occurred in the service sector. According to Renshaw, Trott, and Friedenberg (1988), the share of GSP going to this sector increased in 32 states in each of the five years between 1982 and 1986, while 40 states had their lowest service sector share in 1982 and their largest in 1986. The share of GSP going to the combined service and trade sectors expanded every year in 23 states, while 30 states had their lowest share in 1982 and their largest share in 1986. A corresponding shift away from the manufacturing and construction sectors cannot be as clearly established. There was a monotonic decline in the mining sector in all states that had at least 1 percent of their GSP devoted to mining. However, much of this decline can probably be attributed more to recent changes in the world oil and gas markets than to the industrial restructuring of the U.S. economy.

15. Blackburn and Bloom (1987) examine the differences between earnings and family income inequality.

\section{REFERENCES}

Blackburn, McKinley L., and David E. Bloom. "Earnings and Income Inequality in the United States." Population and Development Review 4 (December 1987): 575-609.

. "The Distribution of Family Income: Measuring and Explaining Changes in the 1980s for Canada and the United States." NBER Working Paper no. 3659. March 1991.

Bluestone, Barry. "The Impact of Schooling and Industrial Restructuring on Recent Trends in Wage Inequality in the United States." American Economic Review Proceedings 80 (May 1990): 303-307.

Bluestone, Barry, and Bennett Harrison. "The Growth of Low-Wage Employment: 1963-86." American Economic Review Proceedings 78 (May 1988): 124-128.

Bound, John, and George Johnson. "Changes in the Structure of Wages During the 1980s: An Evaluation of Alternative Explanations." NBER Working Paper no. 2983. May 1989.

Bradbury, Katharine L. "The Shrinking Middle Class." New England Economic Review (September/October 1986): 41-55.

Braun, Denny. "Multiple Measurements of U.S. Income Inequality." Review of Economics and Statistics 70 (August 1988): 398-405. 
Grubb, W. Norton, and Robert H. Wilson. "Sources of Increasing Inequality in Wages and Salaries, 1960-80." Monthly Labor Review 112 (April 1989): 3-13.

Kakwani, N.C., and N. Podder. "Efficient Estimation of the Lorenz Curve and Associated Inequality Measures from Grouped Observations." Econometrica 44 (January 1976): 137-148.

. "On the Estimation of Lorenz Curves from Grouped Observations." International Economic Review 14 (June 1973): 278-292.

Leonard, Jonathan S., and Louis Jacobson. "Earnings Inequality and Job Tumover." American Economic Review Proceedings 80 (May 1990): 298-302.

Renshaw, Vernon, Edward A. Trott, and Howard L. Friedenberg. "Gross State Product by Industry, 1963-86." Survey of Current Business 68 (May 1988): 30-46.

Slottje, Daniel J. The Structure of Earnings and the Measurement of Income Inequality in the U.S. Amsterdam: North-Holland, 1989.

U.S. Congress, Committee on House Ways and Means. Overview of Entitlement Programs. 101st Congress, 2d session, 1990. 